\title{
Joanna Wygnańska
}

\section{Materiał badawczy z projektu Biografia a tożsamość narodowa (1992-1994) - o archiwizacji zbioru w ramach Archiwum Danych Jakościowych IFIS PAN}

Marek Ziółkowski opisując funkcje przywracania pamięci, zauważa, że: „,pamięć nie dotyczy tego, co się naprawdę zdarzyło w przeszłości, ale tego, jakie użytki czyni z pamięci współczesne pokolenie" (Ziółkowski 1999: 56). Mówienie o istocie pamięci powinno więc odnosić się nie jedynie do treści zapamiętanych zdarzeń, ale raczej do ich interpretacji: ,jak i dlaczego konstruuje się określoną wizję przeszłości” (Szacka 1995: 71).

W ciągu ostatnich dekad refleksja socjologiczna nad tematyką pamięci uległa znacznej intensyfikacji, do czego zapewne przyczyniło się ożywienie badań nad problematyką narodu oraz zainteresowania metodą biograficzną. W badaniach poświęconych problematyce tożsamości narodowej kategorie: pamięci zbiorowej, pamięci komunikacyjnej i kulturowej oraz „dobrej” i ,złej” pamięci pozwalają na wyznaczenie kodów i toposów mówienia o narodowej przestrzeni.

W dorobku badań nad polską tożsamością narodową na uwagę zasługuje opisany w niniejszej publikacji zbiór materiałów zebranych w projekcie Biografia a tożsamość narodowa w latach 1992-1994 przez zespół pracowników Katedry Socjologii Kultury Uniwersytetu Łódzkiego. Tym bardziej zatem cieszy fakt archiwizacji zbioru w Archiwum Danych Jakościowych ${ }^{1}$ afiliowanym przy Instytucie Filozofii i Socjologii Polskiej Akademii Nauk, w której realizacji miałam możliwość uczestniczyć ${ }^{2}$ Podstawowym celem tego Archiwum jest: „zebranie, digitalizacja i archiwizacja w formie cyfrowej zbiorów pochodzących z badań szeroko rozumianych nauk społecznych"’. Dzięki temu możliwa jest ponowna, często pogłębiona refleksja nad danymi, które z biegiem lat stają się źródłami historycznymi oraz ich reanaliza, zakorzeniona w nowych warunkach społeczno-historycznych, tym samym otwierająca kolejne ścieżki ich interpretacji. Dokonując rewizyty zarchiwizowanego materiału warto zwrócić uwagę na czas jego gromadzenia oraz metodę, za pomocą której był zbierany i analizowany. W przypadku omawianego zbioru, autobiograficzne wywiady narracyjne z osobami, które opisują swoją historię życia wplecioną w doświadczenie czasu II wojny, są:

\footnotetext{
1 Strona internetowa Archiwum Danych Jakościowych IFiS PAN: www.adj.ifispan.pl

2 Proces archiwizacji zbioru przypadał na lata 2013-2015.

3 Cytowanie ze strony Archiwum Danych Jakościowych IFiS PAN: www.adj.ifispan.pl/o_archiwum
} 
„zapisem stanu świadomości konkretnych ludzi, w konkretnym czasie, w konkretnej sytuacji” (Filipkowski 2005: 34), co przekłada się na ich niezwykle cenną wartość historyczną, dającą możliwość „oddolnego” odczytania wojennej historii Polski i Kresów Wschodnich wplecionej zazwyczaj w ramy wielkich narracji historycznych.

Zebrane w projekcie Biografia a tożsamość narodowa narracje mogą stanowić wartościowe źródło dla uchwycenia biograficznej pracy nad przeszłością w dyskursie trzech żyjących pokoleń (wojenne, powojenne, pokolenie wnuków), który dla pierwszego zdominowany jest przez bezpośrednie doświadczenie wojny i okresu powojennego. Natomiast dla ostatniego pokolenia relacja na temat rzeczywistości wojennej i powojennej jest zapośredniczona, pracuje w opowieściach o losach starszych generacji. Dodatkowo należy zauważyć, że nosiciele pamięci komunikacyjnej na temat wojny powoli stają się pokoleniem odchodzącym. Nagrane w projekcie wywiady, są zbiorem zasobów znaczeniowych, gdzie „tamten" czas jest rekonstruowany przez narratorów w obrębie narracyjnego „teraz” (Piotrowski 1996: 6). Z tego punktu widzenia zachowana w zebranych wypowiedziach pamięć biograficzna, odnosząca się do zbiorowo-historycznych doświadczeń może stanowić źródło dla interpretowania zawartej w nich wizji przeszłości. Aktualnie, materiały te tworzą nieoceniony zasób historii mówionej. Jak zauważa Kaja Kaźmierska: przypadek ten doskonale pokazuje potrzebę archiwizacji autobiograficznych wywiadów narracyjnych, tutaj dodatkowo dotyczących kwestii historycznie ważnych i społecznie szczególnych, a ściśle wpisanych w kontekst czyjejś indywidualnej biografii (Kaźmierska 2014: 235).

Perspektywa ponownej analizy zarchiwizowanej kolekcji, zgodnie z założeniami tej propozycji, może zatem służyć badaniu nowych problemów badawczych wpisujących się w optykę ,odczytywanych” ponownie tekstów lub też weryfikacji wyników poprzednich badań (Heaton 2008: 35). Do zebranych w latach 90. materiałów biograficznych dotyczących doświadczenia wojennego można się zatem odnieść między innymi w ramach dyskursywnych badań nad tożsamością narodową. Ciekawym spojrzeniem na ten materiał z punktu widzenia odmiennej metodologii badań mogłaby być próba uchwycenia powtarzających się mechanizmów budowania „swoich” i „obcych” przestrzeni narodowych oraz redefinicji pamięci zbiorowej np. w przypadku tożsamości narodowej. W zarchiwizowanej kolekcji odnaleźć można wiele obrazów odmiennych etnicznie tożsamości. Przy czym figura retoryczna „innego”, „obcego” rekonstruowana jest tutaj zarówno poprzez negatywne jak i pozytywne doświadczenie biograficzne w kontekście okupacji.

\section{O archiwizacji zbioru}

Praca nad archiwizacją omawianego zbioru obejmowała w pierwszej kolejności jego uporządkowanie. W ciągu kilku miesięcy przesłuchałam 39 zachowanych kaset z nagraniami wywiadów oraz przeczytałam 57 transkrypcji dostępnych 
w formie maszynopisu i wydruku. W efekcie do digitalizacji trafily 22 nagrania na taśmie magnetofonowej, zaś wszystkie transkrypcje wywiadów zapisano w wersji cyfrowej. Narratorom, których imiona nie były zamaskowane, zmieniłam nazwy, pozostałym pozostawiłam nazwy nadane im jeszcze w trakcie prac nad projektem w latach 90. Na stronie Archiwum Danych Jakościowych znajduje się szczegółowa tabela zawierająca zwięzłą charakterystykę poszczególnych narracji. Powyżej tabeli umieszczono krótki opis zarchiwizowanej kolekcji ${ }^{4}$. Dopiero po uzyskaniu zgody na dostęp do dalszych danych i zobowiązaniu się do przestrzegania warunków korzystania ze zdigitalizowanych materiałów można odsłuchać zachowane nagrania i wczytać się w transkrypcje wywiadów.

Zbiór stanowi barwny i niejednorodny zapis biograficznych doświadczeń II wojny. Natrafiamy w nim zarówno na narracje kresowe (Kresy Wschodnie) oraz narracje z Polski centralnej. Te pierwsze bardzo często zawierają dużo bardziej rozbudowane opisy wojennych doświadczeń oraz ciekawie skonstruowane obrazy innych narodowości. Tym co łączy i wyróżnia wszystkie dostępne wywiady są na pewno zawarte w nich kadry ,żywej historii”. Narratorzy opowiadają o codzienności czasu wojny, która w każdej z narracji przeżywana jest i pamiętana w unikalny sposób. Powtarzalność pewnych doświadczeń nie przesłania zatem indywidualnego biograficznego doświadczenia tamtej rzeczywistości. Większość $\mathrm{z}$ dostępnych w Archiwum wywiadów prezentuje: wysoki poziom indeksalności wypowiedzi, przedstawia uszczegółowione fragmenty zdarzeń biograficznych oraz łączy opowiadane epizody w całości (Rokuszewska-Pawełek 1996: 45). Pozostałe, prezentujące krótsze opowieści dotyczące historii życia i doświadczenia wojennego narratorów, zawierają komponent biograficzny oraz dotykają kwestii ważnych w kontekście przeżywania ówczesnej rzeczywistości.

Wśród 57 zarchiwizowanych narracji natrafić można, między innymi, na opowieść Pani Jadwigi, która swoje doświadczenie wojenne, a zwłaszcza okres pobytu w obozie, spisała również w postaci książki, o której mówi w wywiadzie. Inny narrator, Pan Smolaga jest autorem jedenastu powieści batalistycznych, zaś swoje doświadczenie wojny koncentruje wokół wątku wstąpienia do Wojska Polskiego i okresu bycia rannym w czasie walk o Wał Pomorski. Pani W., córka kolejarza, urodzona w 1913 roku swoją wojenną narrację zahacza także o czas I wojny światowej. W kolekcji dostępny jest też wywiad z Panią Zofią, która po wojnie przez wiele lat prowadziła Koło byłych Więźniarek Ravensbrück. Niezwykle obszerną i bogatą w szczegóły narrację odnajdujemy w opowieści Pana Zygmunta, który rekonstruuje w niej między innymi dramatyczną scenę egzekucji 100 Polaków. Zaś w historii Pana B., który w czasie wybuchu wojny przebywał w Wilnie, a w latach 1943-1945 brał udział w walce partyzanckiej, zawarty jest rozbudowany opis stosunków polsko-litewskich w tamtym okresie. Pani Emilia, która okupację spędziła częściowo na Litwie, na Kresach a później w obozie

4 Adres dostępu do kolekcji na stronie internetowej Archiwum Danych Jakościowych IFiS PAN: www.adj.ifispan.pl/katalog-3 
koncentracyjnym w Oświęcimiu, w wywiadzie w szczegółowy sposób odtwarza to trudne doświadczenie biograficzne. Inna narracja zbudowana przez Panią Ewę, jako jedna z nielicznych, zawiera obserwacje narratorki i jej odczucia związane z losem Żydów w czasie II wojny światowej. W kolekcji zachowana jest także biograficzna opowieść „Kmicica”, który okupację spędził w Wilnie. Pracując jako kurier, podróżował między Wilnem a Warszawą i nielegalnie przekraczał granicę. Nazwę „Kmicic” zawdzięcza sposobowi opowiadania swojej biografii, który przywodzi na myśl język powieści Sienkiewiczowskich. Podobnie z zebranych w projekcie narracji wyróżnia się biograficzna historia Tatara, który swoje doświadczenie tamtego czasu rekonstruuje w niezwykle żywym i barwnym tonie. Narrator operuje językiem literackim, pełnym emocji, nie tylko opisuje, ale także interpretuje rzeczywistość, w której trwa jego opowieść. Wspomniane wywiady stanowią jedynie ilustrację zarchiwizowanego zbioru. Nakreślają jego wielowątkowość i wielowymiarowość doświadczenia wojennego zapisanego w zachowanych biografiach.

Na koniec niniejszego tekstu wypada podzielić się osobistą refleksją. Uczestniczenie w procesie archiwizacji omawianej kolekcji było niewątpliwie ciekawym doświadczeniem badawczym, niosącym za sobą możliwość wysłuchania i przeczytania kilkudziesięciu opowieści o minionej już wojennej i powojennej rzeczywistości. Jako badacz, uczestniczący aktualnie w projektach badawczych opartych o badania biograficzne, byłam zafascynowana zarówno sposobami budowania narracji o tamtym czasie, wielością zapamiętanych zdarzeń i wątków, jak również opisami biograficznego doświadczania obcości narodowej w czasie wojny.

Zarchiwizowane materiały malują zatem, nie tylko obraz społeczeństwa polskiego w okresie II wojny światowej, ale również ukazują typy konstruowania narracji o doświadczeniu biograficznie nacechowanym potencjałem traumy i trajektorii. Jednakże zagłębiając się w przeżycia narratorów, odkrywamy, że są to także opowieści o doświadczeniach okresu ich dzieciństwa i młodości, wplecione nie tylko w te trudne i emocjonalne wątki wojennej codzienności.

\section{Bibliografia}

Filipkowski P., 2005, Po co archiwizować dane jakościowe i jak robia to inni?, [w:] „ASK. Społeczeństwo, badania, metody”, nr 14, s. 31-52

Heaton J., 2008, Secondary analysis of qualitative data: an overview, [w:] "Historical Social Research" (33), s. 33-45

Kaźmierska K., 2014, Autobiograficzny wywiad narracyjny - kwestie etyczne i metodologiczne w kontekście archiwizacji narracji, [w:] „Studia Socjologiczne" nr 3 (214), s. 221-238 
Piotrowski A., 1996, Wstęp, [w:] M. Czyżewski, A. Piotrowski, A. Rokuszewska-Pawełek (red.), Biografia a tożsamość narodowa, Katedra Socjologii Kultury UŁ, Łódź, s. 5-11.

Rokuszewska-Pawełek A., 1996, Miejsce biografii w socjologii interpretatywnej. Program socjologii biografistycznej Fritza Schützego, [w:] „ASK. Społeczeństwo, badania, metody", nr 1, s. 37-54.

Szacka B., 1995, O pamięci społecznej, [w:] „Znak” nr 5, s. 68-76

Ziółkowski M., 1999, Cztery funkcje przywracanej pamięci, [w:] „Studia Socjologiczne" nr 4, s. 55-76. 